\title{
Cottonseed: protein, oil yields, and oil properties as influenced by potassium fertilization and foliar application of zinc and phosphorus
}

\author{
By, Zakaria M. Sawan ${ }^{a, *}$, Saeb A. Hafez ${ }^{\mathrm{b}}$, Ahmed E. Basyony ${ }^{\mathrm{b}}$, and Abou-El-Ela R. Alkassas ${ }^{\mathrm{b}}$ \\ ${ }^{a}$ Cotton Research Institute (zmsawan @ hotmail.com) and \\ ${ }^{\mathrm{b}}$ Food Technology Research Institute, Agricultural Research Center, Ministry of Agriculture \\ \& Land Reclamation, 9 Gamaa Street, 12619, Giza, Egypt.
}

\section{RESUMEN}

Efecto de la fertilización con potasio y de la aplicación foliar de zinc y fósforo en el rendimiento de aceite y proteína y en las propiedades del aceite de algodón.

Para maximizar la cantidad y calidad del valor nutricional de una semilla en términos de ácidos grasos y proteínas es necesario identificar los factores que los afectan y proponer métodos que favorezcan los resultados deseados a través de cambios o mejoras en las prácticas utilizadas. Los experimentos se llevaron a cabo en dos campañas sucesivas en el Agricultural Research Center, Giza, Egipto, en el cultivo "Giza 86" (Gossypium barbadense L.) para estudiar los efectos de la fertilización con potasio (a 0.0 y $47.7 \mathrm{~kg}$ por ha) y las aplicaciones foliares de zinc (a 0.0 y $57.6 \mathrm{~g}$ por ha, dos veces, 70 y 85 días después de la plantación) y fósforo (a $0.0,576,1152$, y $1728 \mathrm{~g}$ por ha, dos veces, 80 y 95 días después de la plantación). La aplicación del potasio junto con la pulverización de las plantas con zinc y fósforo causó un incremento en el rendimiento del algodón, el índice de semilla el contenido graso, los rendimientos de aceite y proteína, e contenido de materia insaponificable en el aceite y el contenido total de ácidos grasos insaturados (oleico y linoleico). Por el contrario estos tratamientos disminuyeron el índice de acidez, el índice de saponificación y el contenido de ácidos grasos saturados. La mayor concentración de fósforo produjo los mejores rendimientos de algodón, de índice de semilla, de los rendimientos de aceite y proteína, y de materia insaponificable en el aceite.

PALABRAS-CLAVE: Algodón - Ácidos grasos - Fósforo Potasio - Propiedades del aceite-Zinc.

\section{SUMMARY}

Cottonseed: protein, oil yields, and oil properties as influenced by potassium fertilization and foliar application of zinc and phosphorus.

In maximizing the quantity and quality of a crop's nutritional value in terms of fatty acids and protein, it is necessary to identify the constraints which may affect it and to devise methods of overcoming them through the use of inputs or changes in management practices. Field experiments were conducted during two successive seasons at the Agricultural Research Center, Giza, Egypt, on the cotton cultivar "Giza 86" (Gossypium barbadense L.) to study the effects of potassium fertilization (at 0.0 and $47.4 \mathrm{~kg}$ of $\mathrm{K}$ $\mathrm{ha}^{-1}$ ) and foliar application of zinc (at 0.0 and $57.6 \mathrm{~g}$ of $\mathrm{Zn}$ ha $^{-1}$, two times, 70 and 85 days after planting, "during square initiation and boll setting stage") and phosphorus (at 0.0 , 576, 1152 and $1728 \mathrm{~g}$ of $\mathrm{P} \mathrm{ha}{ }^{-1}$, two times, 80 and 95 days after planting) on cottonseed. The application of potassium along with spraying plants with zinc and phosphorus caused an increase in cottonseed yield $\mathrm{ha}^{-1}$, seed index, seed oil content, oil and protein yields $\mathrm{ha}^{-1}$, seed oil unsaponifiable matter and total unsaturated fatty acids (oleic and linoleic). However, those treatments resulted in a decrease in oil acid value, saponification value and total saturated fatty acids. The highest $P$ concentration of $1728 \mathrm{~g} \mathrm{ha}^{-1}$ gave the best values of cottonseed yield/ha, seed index, and seed oil and protein yields/ha and oil saponifiable matter.

KEY-WORDS: Cottonseed - Oil fatty acids - Oil properties - Phosphorus - Potassium - Zinc

\section{INTRODUCTION}

In Egypt, the need to increase the national supply of oil and protein, in quantity and quality must be a goal for cotton breeders and producers. Agricultural scientists believe that this challenge can be met. It is expected that plant nutrition, using a balanced fertilization program with both macro and micro-nutrients is becoming very important in the production of high yield with high quality products especially with the large variation in soil fertility and the crop's need for macro and micronutrients. The breeding and production of cotton have traditionally been guided by the consideration of fiber quality and yield. However, cottonseed characteristics except for viability and vigor have generally been ignored. Cottonseed oil is an important source of fat. Also, cottonseed meal is classed as a protein supplement in the feed trade and is almost as important as soybean meal. Potassium, zinc and phosphorus belong to the essential nutrients for crop production and crop reproduction (Pettigrew, 1999; Sharma et al., 1982; Taiz and Zeiger, 1991).

Potassium $(\mathrm{K})$ is an essential macro-element required in large amounts for normal plant growth and development. This attributed to the role of $\mathrm{K}$ in plant biochemical pathways (Marschner, 1995). Potassium increases the photosynthetic rates of crop leaves, $\mathrm{CO}_{2}$ assimilation and facilitates carbon movement (Sangakkara et al., 2000). Furthermore, $\mathrm{K}$ plays an important role in the translocation of photosynthates from sources to sinks (Cakmak et al., 1994). Pettigrew (1999), stated that the elevated carbohydrate concentrations remaining in source tissue, such as leaves, appear to be part of the 
overall effect of $\mathrm{K}$ deficiency in reducing the amount of photosynthate available for reproductive sinks and thereby producing changes in the yield and quality of cotton. Studies have shown increased yield and quality in response to $\mathrm{K}$ fertilization (Zhang et al., 2002). Notable improvements in cotton yield and quality resulting from $\mathrm{K}$ input may be reflected in distinct changes in seed weight and quality.

Crop yields are often limited by low levels of mineral micronutrients in the soil such as zinc (Zn), especially in calcareous soils of arid and semiarid regions. Zinc deficiency occurs in cotton in high-pH soils, particularly where topsoil has been removed in preparing fields for irrigation and thereby exposing the Zn-deficient subsoil. Also, Zn deficiencies have occurred where high rates of $P$ are applied (Oosterhuis et al., 1991). Zinc is an essential mineral nutrient and a cofactor of over 300 enzymes and proteins involved in cell division, nucleic acid metabolism and protein synthesis (Marschner, 1986). Zinc is a component of a number of dehydrogenases, proteinases and peptidases; thus $\mathrm{Zn}$ influences electron transfer reactions including those of the Krebs cycle and hence affects the plant's energy production. Zinc binds tightly to Zn-containing essential metabolites, such as in Zn-activated enzymes, e.g., carbonic anhydrase, which plays a role in photosynthesis and it is localized in the cytoplasm and chloroplasts and may facilitate the transfer of $\mathrm{CO}_{2} / \mathrm{HCO}_{3}^{-}$for photosynthetic $\mathrm{CO}_{2}$ fixation (Sharma et al., 1982).

Phosphorus $(P)$ has been found to be the limiting element in natural ecosystems because it is often bound in highly insoluble compounds and therefore becomes unavailable for plant intake or utilization. High soil $\mathrm{pH}(>7.6)$ and high quantities of $\mathrm{CaCO}_{3}$ result in precipitation of $\mathrm{P}$, which reduces the availability of $P$ (Hearn, 1981). Phosphorus is an essential nutrient and an integral component of several important compounds in plant cells, including the sugar-phosphates involved in respiration, the phospholipids of plant membranes and the nucleotides used in plant energy metabolism and in molecules of DNA and RNA (Taiz and Zeiger, 1991). Rodriguez et al. (1998) observed that with a $\mathrm{P}$ deficiency, there was a reduction in the rate of leaf expansion and in photosynthetic rate per unit of leaf area. Phosphorus, as a constituent of the cell nucleus, is essential for cell division and the development of meristematic tissue (Russell, 1973). Moreover, $P$ plays a decisive role in carbon assimilate transport and metabolic regulation (starch, sucrose biosynthesis) on a whole-plant scale (Bisson et al., 1994). Further, it has a well-known impact on photosynthesis as well as synthesis of nucleic acids, proteins, lipids and other essential compounds (Taiz and Zeiger, 1991).

Due to the economic importance of cottonseed as the main source of edible oil for human consumption and feed for livestock in Egypt, this study was designed. Protein and oil yield, oil properties and fatty acid profiles of oil in the seed of Egyptian cotton ( $G$. barbadense) were measured after potassium fertilization and foliar application of chelated zinc and phosphorus during the square initiation and boll setting stage.

\section{MATERIALS AND METHODS}

Two field experiments were conducted at the Agricultural Research Center, Ministry of Agriculture in Giza, Egypt (30 N, 31 $28^{\circ} \mathrm{E}$ and $19 \mathrm{~m}$ altitude) on the cotton (Gossypium barbadense L.) cultivar "Giza 86", in two successive seasons. The soil type in both seasons was clay loam. The average mechanical analysis (Kilmer and Alexander, 1940) and chemical characteristics (Chapman and Pratt, 1961) of soil in both seasons are recorded in Table 1. A randomized complete block design with four replicates was used. Seeds were planted on the $3^{\text {rd }}$ and the $20^{\text {th }}$ of April in seasons I and II, respectively, in plots having a size of $1.95 \mathrm{~m} \times 4.0 \mathrm{~m}$., including three ridges (after the precaution of border effect was taken into consideration). Hills were spaced $25 \mathrm{~cm}$ apart on one side of the ridge and seedlings were thinned to two plants per hill ${ }^{-1} 6$ weeks after planting, providing for a plant density of 123,000 plants $\mathrm{ha}^{-1}$. The total irrigation amount during the growing season (surface irrigation) was about $6,000-\mathrm{m}^{3} \mathrm{ha}^{-1}$. The first irrigation (after sowing irrigation) was done 3 weeks after sowing and the second was 3 weeks later. Thereafter, the plots were irrigated every 2 weeks until the end of the season, providing a total of nine irrigations. On the basis of soil test results, phosphorus fertilizer was applied at the rate of 54

Table 1

Mechanical and chemical analyses of soil samples

\begin{tabular}{lcc}
\hline \multicolumn{1}{c}{ Season } & I & II \\
\hline Mechanical analysis $^{\mathrm{a}}$ & & \\
Clay (\%) $^{\text {Silt (\%) }}$ & 43.00 & 46.46 \\
Fine sand (\%) & 28.40 & 26.38 \\
Coarse sand (\%) & 19.33 & 20.69 \\
Texture & 4.31 & 1.69 \\
Chemical analysis $^{\mathrm{b}}$ & Clay loam & Clay loam \\
Organic matter (\%) $_{\text {Calcium carbonate (\%) }}$ & \\
Total soluble salts (\%) & 1.83 & 1.92 \\
pH (1:2.5) & 3.00 & 2.73 \\
Total nitrogen (\%) & 0.13 & 0.13 \\
Available nitrogen (mg/kg soil) & 8.10 & 8.08 \\
Available phosphorus (mg/kg soil) & 15.66 & 0.12 \\
Available potassium (mg/kg soil) & 370.00 & 385.00 \\
Available zinc (mg/kg soil) & 1.30 & 1.90 \\
Calcium (meq/100g) & 0.20 & 0.20 \\
\hline
\end{tabular}

a According to Kilmer and Alexander (1940)

${ }^{b}$ According to Chapman and Pratt (1961). Note: The field was divided into uniform soil areas; eight soil samples to plow depth $30 \mathrm{~cm}$ were collected at random over the field and mixed to give a composite sample. 
$\mathrm{kg} \mathrm{P}_{2} \mathrm{O}_{5} \mathrm{ha}^{-1}$ as calcium super phosphate during land preparation. Nitrogen fertilizer was applied at the rate of $144 \mathrm{~kg} \mathrm{~N} \mathrm{ha}^{-1}$ as ammonium nitrate split at two equal doses; the first one was applied after thinning just before the second irrigation and the other one was applied before the third irrigation (the recommended level for semi-fertile soil). Standard cultural practices of the experimental station were used. Each experiment included 16 treatment combinations of the following: (i) Two potassium rates $\left(0.0\right.$ and $47.4 \mathrm{~kg}$ of $\left.\mathrm{K} \mathrm{ha}^{-1}\right)$ were applied as potassium sulfate $\left(\mathrm{K}_{2} \mathrm{SO}_{4}\right.$, " $\left.48 \% \mathrm{~K}_{2} \mathrm{O}\right)$, eight weeks after sowing (as a concentrated band close to the seed ridge) and the application was followed immediately by irrigation. (ii) Two zinc rates $(0.0$ or $57.6 \mathrm{~g}$ of $\mathrm{Zn} \mathrm{ha}{ }^{-1}$ ) were applied as chelated form [ethylenediaminetetraacetic acid (EDTA)] and each was foliar sprayed two times ( 70 and 85 days after sowing, during square initiation and boll stage). (iii) Four phosphorus rates $(0.0,576,1152$ and $1728 \mathrm{~g}$ of $\mathrm{P} \mathrm{ha}^{-1}$ ) were applied as calcium superphosphate $\left(15 \% \mathrm{P}_{2} \mathrm{O}_{5}\right)$ and each was foliar sprayed two times ( 80 and 95 days after sowing). The $\mathrm{Zn}$ and $\mathrm{P}$ were both applied to the leaves with uniform coverage at a volume solution of $960 \mathrm{~L} \mathrm{ha}^{-1}$, using a knapsack sprayer. The pressure used with the sprayer used in the study was $0.4 \mathrm{~kg} / \mathrm{cm}^{2}$, resulting in a nozzle output of $1.43 \mathrm{~L} \mathrm{~min}^{-1}$. The application was carried out between 09.00 and $11.00 \mathrm{~h}$. A summary of all treatments is shown in Table 2.

At harvest $\left(11^{\text {th }}\right.$ and $17^{\text {th }}$ of October in the first and second season, respectively), the total cotton yield plot $^{-1}$ was determined. Following ginning, the cottonseed yields were determined in $\mathrm{kg} \mathrm{ha}^{-1}$, along with seed index weight in $\mathrm{g} / 100$ seeds. Laboratory tests were conducted on a $200-\mathrm{g}$ random sample of seeds representative of each plot. A composite seed sample of the four replicates of each treatment in the two seasons was used for the chemical analyses. The following chemical analyses were conducted: (i) seed crude protein content according to AOAC (1985); (ii) seed oil content in which oil was extracted three times with chloroform/methanol (2:1, vol/vol) mixture according to the method outlined by Kates (1972); (iii) oil quality traits, i.e., refractive index, acid value, saponification value, unsaponifiable matter and iodine value were determined according to methods described by AOCS (1985); and (iv) identification and determination of oil fatty acids by gas-liquid chromatography. The lipid materials were saponified, unsaponifiable matter was removed and the fatty acids were separated. The free fatty acids were methylated with diazomethane (Vogel, 1985). The fatty acid methyl esters were analyzed by a Hewlett Packard model 5890 gas chromatograph (Palo Alto, CA) equipped with dual flame-ionization detectors. The separation procedures were similar to those reported by Ashoub et al. (1989) as follows: The chromatograph was fitted with an FFAP (crosslinked) $30 \mathrm{~m}$ (length) $\times 0.32 \mathrm{~mm}$ (column i.d.) $\times 0.25$ $\mu \mathrm{m}$ (film thickness) capillary column coated with polyethylene glycol. The column oven temperature was programmed at $7{ }^{\circ} \mathrm{C} / \mathrm{min}$ from 50 to $240^{\circ} \mathrm{C}$ and kept constant after $30 \mathrm{~min}$. Injector and detector temperatures were 250 and $260{ }^{\circ} \mathrm{C}$, respectively. Under these conditions, all peaks from C8 to C2O homologous series were well defined. Peak identification was performed by comparison of the relative retention time (RRT) for each peak with those of standard chromatograms. The RRT of oleic acid was given a value of 1.0. Results were expressed as the area percentage of chromatograms.

Statistical analysis. Data obtained for the cottonseed yield and seed index were statistically analyzed as a factorial experiment in a randomized complete block design following the procedure outlined by Snedecor and Cochran (1980) and the least significant difference (L.S.D.) was used to determine the significance of differences between treatment means at 0.05 level. As for the chemical properties considered in the study, the t-test computed in accordance with standard deviation was used to verify the significance between treatment means at the 0.05 level of significance.

\section{RESULTS AND DISCUSSION}

\subsection{Cottonseed yield}

Cottonseed yield per hectare significantly increased when $\mathrm{K}$ was applied (by as much as $13.99 \%$ ) (Table 3). Potassium would have a

Table 2

Treatment numbers and summary

\begin{tabular}{|c|c|c|c|c|c|c|c|}
\hline \multicolumn{3}{|c|}{ Treatments } & \multirow{2}{*}{$\begin{array}{c}\text { Treatment } \\
\text { No. }\end{array}$} & \multicolumn{3}{|c|}{ Treatments } & \multirow[b]{2}{*}{$\begin{array}{c}\text { Treatmen } \\
\text { No. }\end{array}$} \\
\hline $\begin{array}{c}\mathrm{K} \text { rate } \\
\left(\mathrm{kg} \mathrm{ha}^{-1}\right)\end{array}$ & $\begin{array}{l}\text { Zn rate } \\
\left(\mathrm{g} \mathrm{ha}^{-1}\right)\end{array}$ & $\begin{array}{c}\text { P rate } \\
\left(\mathrm{g} \mathrm{ha}^{-1}\right)\end{array}$ & & $\begin{array}{c}\text { K rate } \\
\left(\mathrm{Kg} \mathrm{ha}^{-1}\right)\end{array}$ & $\begin{array}{l}\text { Zn rate } \\
\left(\mathrm{g} \mathrm{ha}^{-1}\right)\end{array}$ & $\begin{array}{c}\text { P rate } \\
\left(\mathrm{g} \mathrm{ha}^{-1}\right)\end{array}$ & \\
\hline \multirow[t]{8}{*}{0.0} & 0.0 & 0.0 & 1 & 47.4 & 0.0 & 0.0 & 9 \\
\hline & & 576 & 2 & & & 576 & 10 \\
\hline & & 1152 & 3 & & & 1152 & 11 \\
\hline & & 1728 & 4 & & & 1728 & 12 \\
\hline & 57.6 & 0.0 & 5 & & 57.6 & 0.0 & 13 \\
\hline & & 576 & 6 & & & 576 & 14 \\
\hline & & 1152 & 7 & & & 1152 & 15 \\
\hline & & 1728 & 8 & & & 1728 & 16 \\
\hline
\end{tabular}


Table 3

Effect of $\mathrm{K}$ rate and foliar application of $\mathrm{Zn}$ and foliar, additional $\mathrm{P}$ on cottonseed yield, seed index, seed oil, seed protein, oil and protein yields

\begin{tabular}{|c|c|c|c|c|c|c|}
\hline Treatments & $\begin{array}{c}\text { Cottonseed } \\
\text { yield } \\
\left(\mathrm{kg} \mathrm{ha}^{-1}\right)^{\mathrm{a}}\end{array}$ & $\begin{array}{l}\text { Seed } \\
\text { index } \\
(g)^{a}\end{array}$ & $\begin{array}{c}\text { Seed } \\
\text { Oil } \\
(\%)^{b}\end{array}$ & $\begin{array}{c}\text { Oil } \\
\text { yield } \\
\left(\mathbf{k g ~ h a}^{-1}\right)^{b}\end{array}$ & $\begin{array}{l}\text { Seed } \\
\text { Protein } \\
(\%)^{b}\end{array}$ & $\begin{array}{c}\text { protein } \\
\text { yield } \\
\left(\mathbf{k g ~ h a}^{-1}\right)^{\mathbf{b}}\end{array}$ \\
\hline \multicolumn{7}{|l|}{$\mathrm{K}$ rate $\left(\mathrm{kg} \mathrm{ha}^{-1}\right)$} \\
\hline $\begin{array}{l}0, \text { control } \\
47.4\end{array}$ & $\begin{array}{l}1828.0 \\
2083.8^{d}\end{array}$ & $\begin{array}{l}10.01 \\
10.16^{d}\end{array}$ & $\begin{array}{l}19.55 \\
19.82^{d}\end{array}$ & $\begin{array}{l}357.5 \\
413.2^{d}\end{array}$ & $\begin{array}{l}22.24 \\
22.27\end{array}$ & $\begin{array}{l}406.6 \\
464.1^{d}\end{array}$ \\
\hline L.S.D. $0.05^{c}$ & 80.61 & 0.054 & - & - & - & - \\
\hline S.D. ${ }^{c}$ & - & - & 0.153 & 34.22 & 0.038 & 36.25 \\
\hline \multicolumn{7}{|l|}{$\overline{\mathrm{Zn} \text { rate }\left(\mathrm{g} \mathrm{ha}^{-1}\right)}$} \\
\hline 0 , control & 1868.3 & 10.04 & 19.59 & 366.2 & 22.25 & 415.7 \\
\hline 57.6 & $2043.5^{d}$ & $10.13^{\mathrm{d}}$ & $19.78^{d}$ & 404.4 & 22.26 & 455.0 \\
\hline L.S.D. $0.05^{c}$ & 80.61 & 0.054 & - & - & - & - \\
\hline S.D. ${ }^{c}$ & - & - & 0.184 & 40.50 & 0.040 & 42.62 \\
\hline \multicolumn{7}{|l|}{$\mathrm{P}$ rate $\left(\mathrm{g} \mathrm{ha}^{-1}\right)$} \\
\hline 0 , control & 1775.8 & 9.97 & 19.56 & 347.5 & 22.23 & 394.8 \\
\hline 576 & $1944.3^{d}$ & $10.08^{\mathrm{d}}$ & 19.64 & 382.1 & 22.25 & 432.7 \\
\hline 1152 & $2023.7^{d}$ & $10.13^{\mathrm{d}}$ & 19.76 & $400.3^{d}$ & 22.26 & $450.5^{\mathrm{d}}$ \\
\hline 1728 & $2079.8^{d}$ & $10.16^{d}$ & 19.77 & $411.5^{\mathrm{d}}$ & 22.28 & $463.3^{d}$ \\
\hline L.S.D. $0.05^{\mathrm{c}}$ & 114.01 & 0.077 & - & - & - & - \\
\hline S.D. C & - & - & 0.202 & 40.21 & 0.040 & 41.78 \\
\hline
\end{tabular}

Combined statistical analysis from the two seasons.

${ }^{b}$ Mean data from a four replicate composites for the two seasons.

${ }^{c}$ L.S.D. = least significant differences, S.D. = standard deviation was used to conduct t-test to verify the significance between every two treatment means at 0.05 level.

dignificant at 0.05 level.

favorable impact on yield components, including a number of open bolls/plant and boll weight, leading to a higher cotton yield. The role of $\mathrm{K}$ suggests that it affects abscission (reduced boll shedding) and it certainly affects yield (Zeng QingFang, 1996). Gormus (2002) also found that K application increased yield.

Application of $\mathrm{Zn}$ significantly increased cottonseed yield per hectare, as compared with the untreated control (by 9.38\%). A possible explanation of such results might be the improvement of yield components due to the application of $\mathrm{Zn}$. Zinc could have a favorable effect on the photosynthetic activity of leaves (Welch, 1995), which improves the mobilization of photosynthates and directly influences boll weight. Further, $\mathrm{Zn}$ is required in the synthesis of tryptophan, a precursor of indole-3-acetic acid (Oosterhuis et al., 1991), which is the major hormone which inhibits abscission of squares and bolls. Thus the number of retained bolls plant ${ }^{-1}$ and consequently cottonseed yield per hectare would be increased (Rathinavel et al., 2000).

Phosphorus extra foliar application at all three concentrations (576, 1152 and $1728 \mathrm{~g}$ of $\mathrm{P} \mathrm{ha} \mathrm{ha}^{-1}$ ) also significantly increased cottonseed yield per hectare, where the three concentrations applied proved to excel the control (by $9.49-17.12 \%$ ). The best yield was obtained at the highest $P$ concentration tested. Such results reflect the pronounced improvement of yield components due to the application of $P$ which is possibly ascribed to its involvement in photosynthesis and translocation of carbohydrates to young bolls (Bisson et al., 1994;
Rodriguez et al., 1998). Phosphorus as a constituent of cell nucleus is essential for cell division and the development of meristematic tissue and hence it would have a stimulating effect on increasing the number of flowers and bolls per plant (Russell, 1973). This result agreed with that reported by Katkar et al. (2002).

On the basis of soil test results, phosphorus fertilizer was applied at the rate of $54 \mathrm{~kg} \mathrm{P}_{2} \mathrm{O}_{5}$ ha $^{-1}$ as calcium super phosphate during land preparation. Generally, the soil nutrients available during the early growth stages, before applying $P$ (as foliar spray), could be sufficient to fulfill the needs of plants to a large extent. However, during the extended period of flowering and boll setting (about 60 days), additional $P$ fertilizer (as foliar spray) might be needed.

\subsection{Seed index}

Seed index significantly increased with the application of $\mathrm{K}$ (Table 3). A possible explanation for the increased seed index due to the application of $\mathrm{K}$ may be due in part to its favorable effects on the photosynthetic activity rate of crop leaves and $\mathrm{CO}_{2}$ assimilation (Sangakkara et al., 2000), which improves mobilization of photosynthates and directly influences boll weight which in turn directly affects seed weight (Ghourab et al., 2000).

The application of $\mathrm{Zn}$ significantly increased seed index as compared to the control. A possible explanation for the increased seed weight might be due to an increased photosynthesis activity 
resulting from the application of $\mathrm{Zn}$ (Welch, 1995) which improves mobilization of photosynthates and the amount of photosynthate available for reproductive sinks and thereby influences boll weight, factors that coincide with increased seed weight (Rathinavel et al., 2000).

The phosphorus applied at all three rates significantly increased seed index over the control. The highest rate of $P\left(1728 \mathrm{~g} \mathrm{ha}^{-1}\right)$ showed the highest numerical value of seed index. A possible explanation for this increased seed weight is the fact that $\mathrm{P}$ activated the biological reaction in the cotton plant, particularly the photosynthesis fixation of $\mathrm{CO}_{2}$ and the synthesis of sugar and other organic compounds (Taiz and Zeiger, 1991). This indicates that treated cotton bolls had larger photosynthetically supplied sinks for carbohydrates and other metabolites than untreated bolls.

\subsection{Seed oil content and yield}

The applied $\mathrm{K}$ caused a significant increase in seed oil content and oil yield per hectare $(55.7 \mathrm{~kg}$ oil $\mathrm{ha}^{-1}$ ), compared with the untreated control (Table 3). This could be attributed to the role of $K$ in biochemical pathways in plants. Potassium increases the photosynthetic rates of crop leaves, $\mathrm{CO}_{2}$ assimilation and facilitates carbon movement (Sangakkara et al., 2000). The favorable effects of $\mathrm{K}$ on seed oil content and oil yield were mentioned by Abou El-Nour et al. (2000).

Spraying plants with $\mathrm{Zn}$ resulted in an increase in seed oil content and oil yield per hectare $(38.2 \mathrm{~kg}$ oil ha $\left.{ }^{-1}\right)$, compared with the untreated control. Cakmak (2000) has speculated that Zn deficiency stress may inhibit some antioxidant enzymes, resulting in extensive oxidative damage to membrane lipids. Similar results were obtained by Rathinavel et al. (2000).

The foliar application of $\mathrm{P}$ at all the three concentrations tended to increase the seed oil content and oil yield per hectare $(34.6-64.0 \mathrm{~kg}$ oil $\mathrm{ha}^{-1}$ ), over the control. The effect was the most significant at the highest $P$ concentration $(1728 \mathrm{~g}$ $\mathrm{ha}^{-1}$ ) on oil yield per hectare. This may be attributed to the fact that $P$ is required for the production of high quality seeds, since it occurs as coenzymes involved in energy transfer reactions; energy is tapped in photosynthesis in the form of adenosine triphosphate (ATP) and nicotinamide adenine dinucleotide phosphate (NADP). This energy is then used in the photosynthetic fixation of $\mathrm{CO}_{2}$ and the synthesis of lipids and other essential organic compounds (Taiz and Zeiger, 1991). These results agreed with those obtained by Rajendran and Veeraputhiran (2001), in sunflower.

\subsection{Seed protein content and yield}

The applied $\mathrm{K}$ caused a slight increase in seed protein content and significantly increased protein yield per hectare $\left(57.5 \mathrm{~kg}\right.$ protein $\left.\mathrm{ha}^{-1}\right)$, compared with the untreated control (Table 3). It also increased the protein yield per hectare, resulting in an improvement in both cottonseed yield and seed protein content. This could be attributed to the role of $\mathrm{K}$ in biochemical pathways in plants. Potassium increases the photosynthetic rates of crop leaves, $\mathrm{CO}_{2}$ assimilation and facilitates carbon movement (Sangakkara et al., 2000). Also, $\mathrm{K}$ has favorable effects on metabolism of nucleic acids and proteins (Bisson et al., 1994; Bednarz and Oosterhuis, 1999; Pettigrew, 1999). These are manifested in metabolites formed in plant tissues and directly influence the growth and development processes. Similar results were obtained by Abou El-Nour et al. (2000), and Ghourab et al. (2000).

The application of $\mathrm{Zn}$ slightly increased the seed protein content and increased protein yield per hectare $\left(39.3 \mathrm{~kg}\right.$ protein $\left.\mathrm{ha}^{-1}\right)$ numerically compared with the untreated control. Because $\mathrm{Zn}$ is directly involved in both gene expression and protein synthesis, Cakmak (2000) has speculated that $\mathrm{Zn}$ deficiency stress may inhibit the activities of a number of antioxidant enzymes, resulting in extensive oxidative damage to proteins, chlorophyll and nucleic acids. These results agreed with those reported by Babhulkar et al. (2000) in safflower.

The phosphorus applied at all rates tended to increase the seed protein content and the protein yield per hectare $\left(37.9-68.5 \mathrm{~kg}\right.$ protein $\mathrm{ha}^{-1}$ ) compared with the untreated control. The effect was significant on protein yield per hectare when applied at a high $\mathrm{P}$ concentration (1728 $\mathrm{g} \mathrm{ha}^{-1}$ ), resulting from an improvement in both cottonseed yield and seed protein content. Best protein yield was obtained at a high $P$ concentration. Phosphorus is a component of nucleic acids, which are necessary for protein synthesis (Taiz and Zeiger, 1991). Similar results were obtained by Tomar et al. (1996) in sunflower.

\subsection{Seed oil properties}

The oil refractive index, unsaponifiable matter and iodine value significantly increased, while saponification value significantly decreased by applying $\mathrm{K}$, compared with the untreated control (Table 4). On the other hand, the acid value was not significantly affected due to the $\mathrm{K}$ application. The increment of the unsaponifiable matter is known to be beneficial for its role in oil stability. Potassium is an essential nutrient and an integral component of several important compounds in plant cells. This attributed to the role of $\mathrm{K}$ in biochemical pathways in plants (Marschner, 1995). These may be reflected in distinct changes in seed oil quality. Mekki et al. (1999) stated that, foliar application of $\mathrm{K}\left(0\right.$ or $\left.3.5 \% \mathrm{~K}_{2} \mathrm{O}\right)$ on sunflower at the seed-filling stage resulted in decreased oil acid content. Froment et al. (2000), in linseed, found that the iodine value, which indicates the degree of unsaturation in the final oil, was highest in treatments receiving extra $\mathrm{K}$. 
Table 4

Effect of $\mathrm{K}$ rate and foliar application of $\mathrm{Zn}$ and foliar, additional $\mathrm{P}$ on seed oil properties ${ }^{\mathrm{a}}$

\begin{tabular}{|c|c|c|c|c|c|}
\hline Treatments & $\begin{array}{l}\text { Refractive } \\
\text { index }\end{array}$ & Acid value & $\begin{array}{c}\text { Saponification } \\
\text { value }\end{array}$ & $\begin{array}{c}\text { Unsaponifiable } \\
\text { matter (\%) }\end{array}$ & $\begin{array}{l}\text { lodine } \\
\text { value }\end{array}$ \\
\hline \multicolumn{6}{|l|}{$\mathrm{K}$ rate $\left(\mathrm{kg} \mathrm{ha}^{-1}\right)$} \\
\hline 0 , control & 1.4684 & 0.1343 & 190.81 & 0.3538 & 127.48 \\
\hline 47.4 & $1.4698^{c}$ & 0.1316 & $189.74^{c}$ & $0.3950^{c}$ & $132.76^{c}$ \\
\hline S.D. ${ }^{b}$ & 0.00136 & 0.00322 & 0.742 & 0.02234 & 3.633 \\
\hline \multicolumn{6}{|l|}{$\overline{Z n}$ rate $\left(\mathrm{g} \mathrm{ha}^{-1}\right)$} \\
\hline 0 , control & 1.4683 & 0.1336 & 190.71 & 0.3625 & 128.39 \\
\hline 57.6 & $1.4699^{c}$ & 0.1323 & $189.84^{c}$ & 0.3863 & 131.85 \\
\hline S.D. ${ }^{\text {b }}$ & 0.00129 & 0.00346 & 0.809 & 0.02870 & 4.211 \\
\hline \multicolumn{6}{|l|}{$\mathrm{P}$ rate $\left(\mathrm{g} \mathrm{ha}^{-1}\right)$} \\
\hline 0 , control & 1.4681 & 0.1350 & 190.75 & 0.3525 & 125.33 \\
\hline 576 & 1.4693 & 0.1343 & 190.33 & 0.3725 & $131.46^{c}$ \\
\hline 1152 & 1.4696 & 0.1323 & 190.10 & 0.3800 & $131.93^{c}$ \\
\hline 1728 & 1.4695 & 0.1309 & 189.92 & 0.3925 & $131.76^{c}$ \\
\hline S.D. ${ }^{b}$ & 0.00152 & 0.00339 & 0.944 & 0.02947 & 3.801 \\
\hline
\end{tabular}

a Mean data from four replicate composites for the two seasons.

b S.D. = standard deviation.

c Significant at 0.05 level.

Spraying plants with $\mathrm{Zn}$ resulted in a significant increase in the oil refractive index, and a significant decrease in unsaponifiable matter, compared with untreated control. The other oil properties (acid, saponification, and iodine values,) were not significantly affected. $\mathrm{Zn}$ activates a large number of enzymes, either due to binding enzymes and substrates, or the effects of $\mathrm{Zn}$ on the conformation of enzymes or substrate, or both (Klug and Rhodes, 1987; Romheld, and Marschner, 1991), these would have a direct impact through utilization in the growth processes, which are reflected in distinct changes in seed oil quality.

The application of $\mathrm{P}$ at all concentrations significantly increased iodine value, compared with the untreated control, while the other oil properties (oil refractive index; acid and saponification values, and the unsaponifiable matter) were not significantly affected. The studied oil quality characteristicss seemed to be enzymatically controlled.

\subsection{Oil fatty acids composition}

The applied $\mathrm{K}$ decreased the oil-saturated fatty acids (capric, lauric, myristic, palmitic and stearic) (Table 5). A significant effect was found only on capric, palmitic, and the total saturated fatty acids. The total unsaturated fatty acids (oleic and linoleic) and the ratio between total unsaturated fatty acids and total saturated fatty acids (TU/TS) was increased (by 4.31 , and $19.77 \%$, respectively) by applied K (Table 6). The effect was significant on linoleic acid, the total unsaturated fatty acids (oleic and linoleic) and the ratio between total unsaturated fatty acids and total saturated fatty acids (TU/TS). The beneficial effect of applied K on TU and TU/TS ratio may be due to the regulated effect of $\mathrm{K}$, which acts as an activator on many enzymaticic processes, where some of these enzymes may affect the seed oil content from these organic matters. To our knowledge, no information on the effect of $\mathrm{K}$ on the cottonseed oil fatty acids is available in the literature. Mekki et al. (1999) stated that, foliar application with $\mathrm{K}$ on sunflower increased the oleic acid fatty acid. Froment et al. (2000), in linseed oil, found that the linoleic acid content was greatest in treatments receiving extra $\mathrm{K}$.

The application of $\mathrm{Zn}$ resulted in a decrease in the saturated fatty acids, i.e. palmitic, capric, myristic, and stearic, and the total but resulted in an increase in lauric acid, compared to the untreated control. The effect was significant only on palmitic acid, and the total saturated fatty acids in the oil. The application of $\mathrm{Zn}$ resulted in an increase in total unsaturated fatty acids (by $3.49 \%$ ) and TU/TS ratio (by $15.25 \%$ ), over the control. The effect was significant on oleic acid, total unsaturated fatty acids (oleic and linoleic) and the ratio between total unsaturated fatty acids and total saturated fatty acids (TU/TS). The stimulatory residual effects of the application $\mathrm{Zn}$ on TU and TU/TS ratio were probably due to the favorable effects of $\mathrm{Zn}$ on fundamental metabolic reactions in plant tissues (Sharma et al., 1982).

The phosphorus applied at all concentrations resulted in a decrease in the total saturated fatty acids compared with the untreated control. Spraying plants with $\mathrm{P}$ at $1728 \mathrm{~g} \mathrm{ha}^{-1}$ gave the lowest total saturated fatty acids oil, followed by $P$ at $1152 \mathrm{~g} \mathrm{ha}^{-1}$ concentration compared with the control. Application at a high P concentration (1728 $\mathrm{g} \mathrm{ha}^{-1}$ ) gave the lowest capric, lauric, palmitic and stearic acid contents compared with the other two concentrations ( 576 and $1152 \mathrm{~g}$ of $\mathrm{P} \mathrm{ha}{ }^{-1}$ ), while applying $P$ at $1152 \mathrm{~g} \mathrm{ha}^{-1}$ gave the lowest myristic acid content compared with the other two concentrations ( 576 and $1728 \mathrm{~g}$ of $\mathrm{P} \mathrm{ha}{ }^{-1}$ ). The effect was significant for the two concentrations 1152 and $1728 \mathrm{~g}$ of $\mathrm{P} \mathrm{ha}-1$ on capric acid and the total saturated fatty acids in the oil, and for all 
Table 5

Effect of $\mathrm{K}$ rate and foliar application of $\mathrm{Zn}$ and foliar, additional $\mathrm{P}$ on the relative percentage of saturated fatty acids ${ }^{a}$

\begin{tabular}{|c|c|c|c|c|c|c|}
\hline \multirow{2}{*}{ Treatments } & \multicolumn{6}{|c|}{ Relative $\%$ of saturated fatty acids } \\
\hline & Capric & Lauric & Myristic & Palmitic & Stearic & Total \\
\hline \multicolumn{7}{|l|}{$\mathrm{K}$ rate $\left(\mathrm{kg} \mathrm{ha}^{-1}\right)$} \\
\hline 0, control & 0.0774 & 0.0626 & 0.8275 & 22.21 & 2.271 & 25.4525 \\
\hline 47.4 & $0.0728^{c}$ & 0.0599 & $0.4863^{c}$ & $19.72^{\mathrm{c}}$ & 1.915 & $22.2501^{\circ}$ \\
\hline S.D. ${ }^{\mathrm{b}}$ & 0.00369 & 0.00794 & 0.34079 & 1.482 & 0.4512 & 2.33093 \\
\hline \multicolumn{7}{|l|}{$\mathrm{Zn}$ rate $\left(\mathrm{g} \mathrm{ha}^{-1}\right)$} \\
\hline 0, control & 0.0769 & 0.0609 & 0.6763 & 22.16 & 2.185 & 25.1590 \\
\hline 57.6 & 0.0733 & 0.0616 & 0.6375 & $19.77^{\mathrm{C}}$ & 2.001 & 22.5436 \\
\hline S.D. ${ }^{b}$ & 0.00400 & 0.00496 & 0.38598 & 1.796 & 0.4798 & 2.53159 \\
\hline \multicolumn{7}{|l|}{$P$ rate $\left(\mathrm{g} \mathrm{ha}^{-1}\right)$} \\
\hline 0 , control & 0.0795 & 0.0665 & 1.1075 & 22.80 & 2.728 & 26.7760 \\
\hline 576 & $0.0748^{c}$ & $0.0623^{c}$ & $0.5925^{c}$ & 20.70 & $1.855^{\mathrm{C}}$ & $23.2870^{\circ}$ \\
\hline 1152 & $0.0733^{c}$ & $0.0595^{c}$ & $0.4375^{c}$ & 20.30 & $1.905^{\mathrm{C}}$ & $22.7703^{\circ}$ \\
\hline 1728 & $0.0728^{c}$ & $0.0568^{c}$ & $0.4900^{\circ}$ & 20.07 & $1.885^{\mathrm{c}}$ & $22.5720^{\circ}$ \\
\hline S.D. ${ }^{b}$ & 0.00368 & 0.00340 & 0.28269 & 2.026 & 0.3173 & 2.42171 \\
\hline
\end{tabular}

${ }^{a}$ Mean data from a four replicate composites for the two seasons.

${ }^{b}$ S.D. = standard deviation.

Significant at 0.05 level.

Table 6

Effect of $\mathrm{K}$ rate and foliar application of $\mathrm{Zn}$ and foliar, additional $\mathrm{P}$ on the relative percentage of unsaturated fatty acids ${ }^{a}$

\begin{tabular}{|c|c|c|c|c|}
\hline \multirow{2}{*}{ Treatments } & \multicolumn{3}{|c|}{ Relative $\%$ of unsaturated fatty acids } & \multirow{2}{*}{${ }_{\text {ratio }}^{\text {TU/TS }}$} \\
\hline & Oleic & Linoleic & Total & \\
\hline \multicolumn{5}{|l|}{$\mathrm{K}$ rate $\left(\mathrm{kg} \mathrm{ha}^{-1}\right)$} \\
\hline 0 , control & 21.61 & 52.94 & 74.54 & 2.954 \\
\hline 47.4 & 22.73 & $55.01^{d}$ & $77.75^{\mathrm{d}}$ & $3.538^{d}$ \\
\hline S.D. ${ }^{c}$ & 1.407 & 1.498 & 2.332 & 0.4037 \\
\hline \multicolumn{5}{|l|}{$\mathrm{Zn}$ rate $\left(\mathrm{g} \mathrm{ha}^{-1}\right)$} \\
\hline 0 , control & 21.43 & 53.40 & 74.84 & 3.016 \\
\hline 57.6 & $22.90^{d}$ & 54.55 & $77.45^{d}$ & $3.476^{\mathrm{d}}$ \\
\hline S.D & 1.311 & 1.761 & 2.533 & 0.4469 \\
\hline \multicolumn{5}{|l|}{$P$ rate $\left(\mathrm{g} \mathrm{ha}^{-1}\right)$} \\
\hline 0 , control & 21.11 & 52.11 & 73.22 & 2.755 \\
\hline 576 & 21.96 & $54.75^{d}$ & $76.71^{d}$ & $3.331^{d}$ \\
\hline 1152 & 22.52 & $54.70^{d}$ & $77.23^{\mathrm{d}}$ & $3.427^{d}$ \\
\hline 1728 & $23.09^{d}$ & $54.33^{d}$ & $77.43^{\mathrm{d}}$ & $3.472^{d}$ \\
\hline S.D. ${ }^{c}$ & 1.421 & 1.571 & 2.422 & 0.4392 \\
\hline
\end{tabular}

${ }^{a}$ Mean data from four replicate composite for the two seasons.

${ }^{b}$ TU/TS ratio = (total unsaturated fatty acids) / (total saturated fatty acids).

${ }^{c}$ S.D. = standard deviation

${ }^{\mathrm{d}}$ Significant at 0.05 level.

different $\mathrm{P}$ concentrations on lauric, myristic, and stearic. Phosphorus applied at all rates increased the total unsaturated fatty acid (by $4.77-5.75 \%$ ) and TU/TS ratio (by 20.91-26.03\%) compared with untreated control. Applied $\mathrm{P}$ at $1728 \mathrm{~g} \mathrm{ha}^{-1}$ gave the highest increment, followed by the concentration $1152 \mathrm{~g}$ of $\mathrm{P} \mathrm{ha} \mathrm{h}^{-1}$. Spraying plants with $\mathrm{P}$ at $1728 \mathrm{~g}$ $\mathrm{ha}^{-1}$ produced seed oil characterized by the highest oleic acid content, while spraying with $576 \mathrm{~g}$ of $\mathrm{P}$ $\mathrm{ha}^{-1}$ gave the highest linoleic acid content compared with the other concentrations. The effect was significant for the high $\mathrm{P}$ concentration $(1728 \mathrm{~g}$ $\mathrm{ha}^{-1}$ ) on oleic, for the two concentrations, 1152 and $1728 \mathrm{~g}$ of $\mathrm{P} \mathrm{ha}^{-1}$ on the TU/TS ratio, and for all different concentrations on linoleic, and total unsaturated fatty acids. The beneficial effect of applied $\mathrm{P}$ at different concentrations on TU and the TU/TS ratio may be due to the regulated effect of $P$ on many enzymatic processes and the fact that $P$ also acts as an activator of some enzymes (Epestein, 1971) which may affect the seed oil fatty acid composition. Gushevilov and Palaveeva (1991) studied the changes in the contents of linoleic, oleic, stearic and palmitic acids in sunflower oil due to the P-application rate and found that oil quality remained high at a high P-rate. Khan et al. (1997) indicated that oleic acid increased by increasing levels of $\mathrm{P}$ added to rapeseed-mustard.

High properties of unsaturated fatty acids are desirable for edible oils. Especially high levels of 
linoleic acid and oleic acid are considered good for oil quality (Downey and Rimmer, 1993).

During the two growing seasons no significant interactions were found between the variables in the present study (application of $\mathrm{K}, \mathrm{Zn}$ and $\mathrm{P}_{2} \mathrm{O}_{5}$ concentrations) on quantitative and qualitative characteristicss under investigation. Regarding insignificant interaction effects, the $F$ ratios worthy exceed unity, but within the level of probability take $\mathrm{P} \leq 0.05$, they did not show significance.

\section{CONCLUSIONS}

From the findings of the present study, the addition of $\mathrm{K}$ at $47.4 \mathrm{~kg} \mathrm{ha}^{-1}$, spraying cotton plants with $\mathrm{Zn}$ twice (at $57.6 \mathrm{~g} \mathrm{ha}^{-1}$ ), the foliar application of $P$, also twice (especially the $P$ concentration of $1728 \mathrm{~g} \mathrm{ha}^{-1}$ ) along with the soil fertilization used $P$ at sowing time have been proven beneficial to the quality and yield of cotton plants. These combinations appeared to be the most effective treatments, affecting not only the quantity but also the quality of oil, and to obtain higher oil and protein yields and a better fatty acid profile in the oil of cotton. In comparison with the ordinary cultural practices adopted by Egyptian cotton producers, it is apparent that the applications of such treatments could produce an improvement in cottonseed yield, seed protein content, oil and protein yields, oil refractive index, unsaponifiable matter, iodine value, unsaturated fatty acids and a decrease in oil acid value and saponification value. The increase in seed yield and the subsequent increase in oil and meal due to the addition of $\mathrm{K}$, spraying cotton plants with $\mathrm{Zn}$ and the addition of $\mathrm{P}$ are believed to be sufficient to cover the cost of using those chemicals and obtain an economic profit at the same time.

\section{REFERENCES}

Abou El-Nour MS, Saeed MA, Morsy MA. 2000. Effect of potassium fertilization under two planting dates on yield, yield components and some technological and chemical properties of Giza 80 cotton cultivar. Egypt. J. Agric. Res. 78, 1219-1231.

Ashoub AH, Basyony AE, Ebad FA. 1989. Effect of plant population and nitrogen levels on rapeseed oil quality and quantity. Annals Agric. Sci., Moshtohor 27, 761770.

American Oil Chemists' Society 1985. Official Methods and Recommended Practices of the American Oil Chemists' Society, edited by R.O. Walker, Champaign.

Association of Official Analytical Chemists 1985. Official Methods of Analysis, 14th ed.; AOAC, Arlington, VA.

Babhulkar PS, Kar Dinesh, Badole WP, Balpande SS. 2000. Effect of sulphur and zinc on yield, quality and nutrient uptake by safflower in Vertisol, J. Indian Soc. Soil Sci. 48, 541-543.

Bednarz CW, Oosterhuis DM. 1999. Physiological changes associated with potassium deficiency in cotton. J. Plant Nutr. 22, 303-313.
Bisson P, Cretenet M, Jallas E. 1994. Nitrogen, phosphorus and potassium availability in the soilphysiology of the assimilation and use of these nutrients by the plant. Challenging the Future: Proceedings of the World Cotton Research Conference-1, Brisbane Australia, February 14-17, G. A. Constable and N. W. Forrester (eds), CSIRO, Melbourne, pp. 15-124.

Cakmak I. 2000. Possible roles of zinc in protecting plant cells from damage by reactive oxygen species. New Phytol. 146, 185-205.

Cakmak I, Hengeler C, Marschner H. 1994. Partitioning of shoot and root dry matter and carbohydrates in bean plants suffering from phosphorus, potassium and magnesium deficiency. J. Exp. botany 45, 1245-1250.

Chapman HD, Pratt PE. 1961. Methods of Analysis of Soils, Plants and Waters, University of California, Division of Agricultural Science: Los Angeles, pp 6061, 159-179.

Downey RK, Rimmer SR. 1993. Agronomic improvement in oil seed Brassicas. Adv. Agr. 50, 1-66.

Epestein E. 1971. Mineral Nutrition of Plants Principles and Perspective, John Wiley, and Sons, Inc., New York.

Froment MA, Turley D, Collings LV. 2000. Effect of nutrition on growth and oil quality in linseed. Tests of Agrochemicals and Cultivars No. 21, 29-30.

Ghourab MHH, Wassel OMM, Raya NAA. 2000. Response of cotton plants to foliar application of (Pottasin-P) ${ }^{\mathrm{TM}}$ under two levels of nitrogen fertilizer. Egypt. J. Agric. Res. 78, 781-793.

Gormus O. 2002. Effects of rate and time of potassium application on cotton yield and quality in Turkey, $\mathrm{J}$. Agron. Crop Sci. 188, 382-388.

Gushevilov Zh, Palaveeva Ts. 1991. Effect of long-term systematic fertilizer application on sunflower yield and quality. Pochvoznanie i Agrokhimiya 26, 20-26.

Hearn AB. 1981. Cotton nutrition. Field Crop Abst. 34, 1134.

Kates M. 1972. Laboratory Techniques in Biochemistry and Molecular Biology edited by T.S. Work, and E. Work, North-Holland Publishing, Amsterdam.

Katkar RN, Turkhede AB, Solanke VM, Wankhade ST, Sakhare BA. 2002. Effect of foliar sprays of nutrients and chemicals on yield and quality of cotton under rain fed condition. Research on Crops 3, 27-29.

Khan NA, Ansari HR, Samiullah 1997. Effect of gibberellic acid spray and Basal nitrogen and phosphorus on productivity and fatty acid composition of rapeseedmustard. J. Agron. Crop Sci. 179, 29-33.

Kilmer VJ, Alexander LT. 1940. Methods of making mechanical analysis of soils. Soil Sci. $\mathbf{6 8}, 15$.

Klug A, Rhodes D. 1987. "Zinc fingers": A novel protein motif for nucleic acid recognition. Trends Biochem. Sci. 12, 464-469.

Marschner H. 1986. Functions of mineral nutrients: macronutrients. In: Mineral Nutrition of Higher Plants, Academic Press, Orlando, FL., pp. 195-267.

Marschner H. 1995. Mineral Nutrition of Higher Plants, Second Edition, London, UK: Academic Press.

Mekki BB, El-Kholy MA, Mohamed EM. 1999. Yield, oil and fatty acids content as affected by water deficit and potassium fertilization in two sunflower cultivars. Egypt. J. Agron. 21, 67-85.

Oosterhuis D, Hake K, Burmester C. 1991. Foliar feeding cotton. Cotton Physiol. Today 2 (July): 1-7 (Cotton Council of America).

Pettigrew WT. 1999. Potassium deficiency increases specific leaf weights of leaf glucose levels in fieldgrown cotton. Agron. J. 91, 962-968. 
Rajendran K, Veeraputhiran R. 2001. Phosphorus nutrients in sunflower-a review. Agric. Rev. 22, 68-70.

Rathinavel K, Dharmalingam C, Paneersel vam S. 2000. Effect of micronutrient on the productivity and quality of cotton seed cv. TCB 209 (Gossypium barbadense L.). Madrase Agric. J. 86, 313-316.

Rodriguez D, Zubillaga MM, Ploschuck E, Keltjens W, Goudriaan J, Lavado R. 1998. Leaf area expansion and assimilate prediction in sunflower growing under low phosphorus conditions. Plant Soil 202, 133-147.

Romheld V, and Marschner H. 1991. Micronutrients in Agriculture, $2^{\text {nd }}$ ed. Soil Science Society of America Book Series, no 4, Published by: Soil Science Society of America, Inc., Madison, Wisconsin, USA, pp. 297-328.

Russell EW. 1973. Soil Condition and Plant Growth, The English Language Book Society and Longman, London.

Sangakkara UR, Frehner M, Nosberger J. 2000. Effect of soil moisture and potassium fertilizer on shoot water potential, photosynthesis and partitioning of carbon in mungbean and cowpea. J. Agron. Crop Sci. 185, 201207.

Sharma CP, Sharma PN, Bisht SS, Nautiyal BD. 1982. Zinc deficiency induced changes in cabbage. In: A. Scaife (ed.), Proc. $9^{\text {th }}$ Plant Nutr. Colloq., Warwick, England, 22-27 Aug. Commonwealth Agric. Bur. Farnham House, Slough, England, pp. 601-606.
Snedecor GW, Cochran WG. 1980. Statistical Methods, 7th edn., lowa State University Press, Ames.

Taiz L, Zeiger E. 1991. Plant Physiology: Mineral Nutrition, The Benjamin Cummings Publishing Co., Inc. Redwood City, CA.

Tomar HPS, Dadhwal KS, Singh HP. 1996. Oil content, oil and cake yield and protein content of sunflower (Helianthus annuus L.) as influenced by irrigation, nitrogen and phosphorus levels. Indian J. Soil Conservation 24, 215-220.

Vogel Al. 1975. A Textbook of Practical Organic Chemistry, 3rd edn., English Language Book Society and Longman Group, Essex.

Welch RM. 1995. Micronutrient nutrition of plants. CRC Crit. Rev. Plant Sci. 14, 49-82.

Zeng QingFang 1996. Experimental study on the efficiency of $\mathrm{K}$ fertilizer applied to cotton in areas with cinnamon soil or aquic soil. China Cottons 23, 12.

Zhang XueBin, Wang LiGang, Wang JiYin, Chen DongYi, Zhao JinCai, Chen QingLai, Song JingKel, Wei JinSuo. 2002. Studies on the effect of potassium fertilizer applied to cotton in the medium and low yield cotton growing area in Henan Province. China Cottons 29, 9.

Recibido: Marzo 2006 Aceptado: Noviembre 2006 